\title{
Inhibitor Effect of Anthocleista djalonensis Extract on the Corrosion of Concrete Steel Reinforcement
}

\author{
Gengfang Xie ${ }^{*}$, Liu Wei
}

School of architecture, Chang'an University, Xi'an, Shaanxi, 710064, P.R. China

*E-mail: gengfangxie_hi@163.com

doi: $10.20964 / 2018.06 .12$

Received: 7 February 2018 / Accepted: 21 March 2018 / Published: 10 May 2018

In the present study, the anticorrosion behaviour of the leaf-extract admixture of Anthocleista djalonensis (A. djalonensis) on steel-reinforced concrete immersed in an $\mathrm{HCl}$ solution (as an aggressive medium) was investigated using electrochemical methods. Monitoring-related parameters included the corrosion rate, corrosion potential, and corrosion current. The performance of this novel eco-friendly corrosion inhibitor was investigated at various temperatures $\left(25-60{ }^{\circ} \mathrm{C}\right)$ at various concentrations $(0.1$ to $0.4 \mathrm{~g} / \mathrm{L})$.

Keywords: Corrosion of steel reinforcement; Inhibitor; Inhibition efficiency; Anthocleista djalonensis

\section{$\underline{\text { FULL TEXT }}$}

(C) 2018 The Authors. Published by ESG (www.electrochemsci.org). This article is an open access article distributed under the terms and conditions of the Creative Commons Attribution license (http://creativecommons.org/licenses/by/4.0/). 